\title{
ANCIENT GREEK FOLKSONG TRADITION ${ }^{1}$
}

Summary: The aim of my paper is to outline an overview of the collection of the Carmina popularia. In particular, I will criticise the modus operandi employed so far in arranging this corpus and meditate on what can be deemed 'folk song' in ancient Greece. As case studies, I shall take the five begging songs handed down to us. I shall also provide a revised text and a critical apparatus for each poem.

Key words: folksong, carmina popularia, begging songs, eiresione, chelidonism, koronisma

\section{STATE OF THE ART}

Since the 19th century, editors have gathered together a series of anonymous melic poems under the label Carmina popularia. They are characterized by their plain style and irregular metrical form and can neither be attributed to a genre nor to an authorial model. ${ }^{2}$ As a result, a corpus - or rather a corpusculum - has been formed, outside the official body of 'high' poetry, divided into specific genera and authors. In modern terms they would be defined as 'popular/folk songs ${ }^{3}$ consisting of e.g. begging songs, love songs, work songs, war songs, nursery rhymes, dance songs, ritual songs and so on.

${ }^{1}$ This paper contains some of the most significant results featured in my Master Thesis entitled I canti di questua della Grecia antica: edizione critica, traduzione e commento (The Begging Songs of Ancient Greece: Critical Edition, Translation and Commentary). I defended it on 25th September 2013 at the University of Bologna. Professor Camillo Neri and Professor Federico Condello acted as supervisors.

${ }^{2}$ Here I mean those texts whose 'historical authors' are unknown: cf. PALMISCIANO, R.: Submerged Literature in an Oral Culture. In COLESANTI, G. - GIORDANO M. (eds.): Submerged Literature in Ancient Greek Culture. Berlin-Boston 2014, 19-32, here $20 \mathrm{f}$.

3 «Classicists tend to use the terms 'popular song' and 'folk song' interchangeably» (YATROMANOLAKIS, D.: Ancient Greek Popular Song. In Budelmann, F. [ed.]: The Cambridge Companion to Greek Lyric. Cambridge 2009, 263-276, here 263, n. 3). On these conventional markers, see n. 9. 
In the wake of the pioneering efforts of Ilgen in 1797 (his publication was exclusively devoted to Begging Songs) and of Zell in 1826, the first systematic collection was that of Köster published in $1831 .{ }^{4}$ Several publications followed. ${ }^{5}$ Neri's edition is based on Page's sylloge ( $P M G$ 847-883, which is today seen as the most authoritative reference collection), and represents the most recent overall collection of melic 'popular' poems; a translation, a synthetic commentary and exhaustive bibliographical notes accompany it. ${ }^{6}$

While most of these scholars provide an overview of songs that have never been incorporated into 'high' literature, they do not take into account the traditional background of these texts. Consequently, some specific issues and aspects are not dealt with. Here I refer specifically to (1) the preservation and transmission of this type of texts; (2) their relationship with 'high' and 'official' literature; (3) their relationship with modern folksong tradition. Therefore I am fully convinced that a new edition accompanied by a commentary is needed, in particular one that is aware of these specific challenges.

In order to fill this current gap in classical studies, I have decided to direct my $\mathrm{PhD}$ research efforts towards the preparation of a new corpus of Popularia,

${ }^{4}$ ILGEN, C. D.: EIPE $\Sigma I \Omega N H$ Homeri et alia poeseos mendicorum Graecorum specimina cum nonnullis nostri temporis carminibus ex hoc genere comparata. In ILGEN, C. D.: Opuscula varia philologica. Vol. I-II. Erfordiae 1797, I 129-184; ZELL, K.: Über die Volkslieder der alten Griechen. In ZELL, K.: Ferienschriften. Vol. I-II. Freiburg 1826, I 53-90; KÖSTER, H.: De cantilenis popularibus veterum Graecorum. Berolini 1831.

${ }^{5}$ SCHNEIDEWIN, F. W.: Delectus poesis Graecorum Elegiacae, Iambicae, Melicae. Vol. I-II. Gottingae 1838-1839, II 456-467; BERGK, T.: Poetae Lyrici Graeci. Lipsiae $1882^{4}\left(1843^{1}, 1853^{2}\right.$, [1866-] $1867^{3}$ ), 654-688; SMYTH, H. W.: Greek Melic Poets. London 1900, 154-162; DiEHL, E.: Anthologia Lyrica Graeca. Vol. I-II. Lipsiae 1925, II 192-208; EDMONDS, J. M.: Lyra Graeca. Vol. I-III. Cambridge, Mass. - London 1928-1940² (1922-1927¹), III 488-549; PAGE, D. L.: Poetae Melici Graeci. Oxford 1962, 450-470; NERI, C.: Sotto la politica. Una lettura dei Carmina popularia melici. Lexis 21 (2003) $193-255$.

${ }^{6}$ See also CERRATO, L.: I canti popolari della Grecia antica. RFIC 13 (1885) 193-260, 289-368; LAMBIN, G.: La chanson grecque dans l'antiquité. Paris 1992. Without distinguishing between authorial poetry and traditional poetry, both scholars searched for the element of 'popular' in both. For an overview of stylistic, linguistic and metrical features in the Carmina popularia, see PORDOMINGO, F.: La poesía popular griega: aspectos histórico-literarios y formas de transmisión. In PECERE, O. - STRAMAGLIA, A. (a cura di): La letteratura di consumo nel mondo greco-latino. «Atti del Convegno Internazionale. Cassino, 14-17 settembre 1994». Cassino 1996, 461-482. Cf. also PoRDOMINGO, F.: Las citas de Carmina popularia en Plutarco. In D'ippolito, G. - GAllo, I. (a cura di): Strutture formali dei Moralia di Plutarco. Atti del III Convegno plutarcheo. Palermo, 3-5 maggio 1989. Napoli 1991, 213-224; PordOMINGO, F.: Poesía popular y poesía literaria griegas: relaciones intertextuales. In BÉCARES, V. et al. (eds.): Intertextualidad en las literaturas Griega y Latina. Madrid 2000, 77-104; PALMISCIANO, R.: È mai esistita la poesia popolare nella Grecia antica? In NiCOLAI, R. (a cura di): Rysmos. Studi di poesia, metrica e musica greca offerti dagli allievi a L.E. Rossi per $i$ suoi settant'anni. Roma 2003, 151-171; YATROMANOLAKIS (n. 3); MAGNANI, M.: Note marginali ai Carmina popularia. Eikasmós 24 (2013) 45-66. On the origin and development of the collection - with an analysis of the tradition, metre and content of the texts contained in it - see MAgnAnI, M.: Carmina popularia: origine e sviluppo della raccolta. Paideia 58 (2013) 543-573.

${ }^{7}$ An attempt in this direction was that of Pordomingo, F.: La poesía popular griega. Estudio filológico y literario. Diss. doct. ined. Salamanca 1979 (cf. PoRDOMINGO, F.: Resumenes de tesis doctorales. Facultad de filología - Univ. de Salamanca T-L-F-5/1979). 
completed with a systematic commentary, revised text, critical apparatus and translation in modern English.

Let us look at the nature of this new collection. Is Page's sylloge already complete and definitive or does it require revision and updating? In this latter case, the first step should consist in identifying, within Greek literature, those songs which merit inclusion in the category of Popularia. However, one question arises spontaneously. ${ }^{8}$

\section{DID ANCIENT GREEK POPULAR POETRY EVER EXIST?}

The definition of 'popular' has long been recognised as problematic - and not only in the narrow field of classical studies. ${ }^{9}$ The most common approaches used to define the notion of 'a popular song' or, more generally, 'popular culture' are based on binary opposites such as 'low-high', 'many-few', 'oral-written', 'simple-complex', 'anonymous-authorial', 'periphery-centre' and so forth. Nevertheless, each of these two-tier models involves a series of conceptual difficulties.

Take, for example, the case of the first two opposites: 'low-high' and 'manyfew'. They encompass a range of definitions, which can be termed either 'quantitative' or 'qualitative' respectively. The former implies a sort of aesthetic bias, following which all of the popular literature is to be seen as the product of talentless authors and thus catalogued as bad literature. It is rather like saying that in every era and society there have existed two completely distinct cultures: the culture of ordinary people and the culture of the elite. However, we are now well aware of the vagueness of boundaries separating learned culture and 'popular' culture. They are - it can no longer be denied - intersecting sets.

The latter definition has the definite plus of not using an evaluative criterion, merely a descriptive one. All the same, problems remain. It implies that the more a literary genre is well known and liked by people, the more popular it is. Although we manage to find "a figure over which something becomes popular culture, and below which it is just culture", ${ }^{10}$ we could be faced with an excessively large amount of heterogeneous material.

Nor can we draw on the opposites 'oral and written' and regard the oral mode of diffusion as a guarantee of 'popular songs'. Even if this were so, it would not ring true, because we would be forced to use a dichotomy that does not belong to all

\footnotetext{
${ }^{8}$ The query put by PALMiSCIANO (n. 6).

${ }^{9}$ For a general discussion, see e.g. HANSEN, W. (ed.): Anthology of Ancient Greek Popular Literature. Bloomington-Indianapolis 1998, xi-xxiii; BURKE, P.: Popular Culture in Early Modern Europe. Farnham $2009^{3}$ (London $1978^{1}$ ), xvi-xxvii; PARKER, H. N.: Toward a Definition of Popular Culture. $H \& T$ 50 (2011) 147-170. Needless to say, along with 'popular', terms as 'folk', 'folkloric' and 'traditional' all share similar definition problems: cf. e.g. YATROMANOLAKIS (n. 3) 264 (esp. ns. 6 and 9); MAGNANI: Carmina (n. 6) 560 n. 67.

${ }^{10}$ STOREY, J.: Cultural Theory and Popular Culture: An Introduction. Athens $2006^{4}$, 4; quoted by PARKER (n. 9) 150.
} 
societies of all ages. ${ }^{11}$ There appears to be a vicious circle: by adopting any one of the aforementioned definitions, some problems and ambiguities are indeed smoothed out, but others are created at the same time.

In view of such, albeit brief, considerations, clearly a univocal definition of 'popular' is still distant from general acceptance. The lack of this type of theorisation is much more evident in studies in antiquity. ${ }^{12}$

To quote Yatromanolakis, "There is no doubt that in archaic, classical and Hellenistic Greece anonymously transmitted song-making traditions existed." 13 Indeed, there is no lack of information about this part of ancient culture. ${ }^{14}$ Traditional ritual songs are already attested in Homer's poems. For instance, the $\lambda$ ívos, which is generally assumed to be a song of lamentation, possibly performed by particular categories of working people, is described in Il. XVIII 569-572 as well as in Hdt. II 79. It is also opportune to quote Ath. XIV 618c-620a. In this passage, the erudite, through his sources, provides a sort of summary of the names, characteristics and origins of some songs that evidently belonged to the folkloric heritage of Greece. The songs dealt with

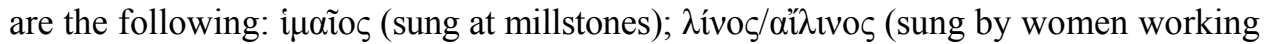

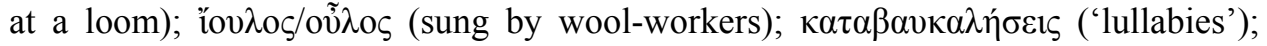
$\dot{\alpha} \lambda \tilde{\eta} \tau \iota \varsigma$ (sung at the 'Swing/Noose' Festival); $\Lambda \iota \tau v \varepsilon ́ p \sigma \eta \varsigma$ (sung by harvesters); others sung by hired labourers, bath-men or women winnowing grain; pastoral songs ( $\beta$ ov-

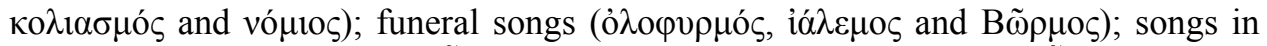

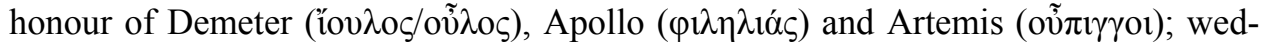

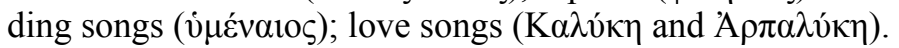

Nevertheless, it has to be clarified that no ancient Greek terms can be found that perfectly translate the modern category of 'folk song', as opposed to the authorial and literary production. There are occurrences of terms that derive from the same root as $\delta \tilde{\eta} \mu \mathrm{s}$, but none of them can be compared to the modern notions of 'folk song' or 'folk culture', whatever these last ones may mean. ${ }^{15}$ Among the most significant examples, it is worth mentioning the term $\delta \alpha \mu \omega ́ \mu \alpha \tau \alpha$, which occurs in Stesich. PMGF 212 and

${ }^{11}$ Cf. YATROMANOLAKIS (n. 3) 264f. Even the term 'oral' raises a series of theoretical and methodological problems. It will be enough to remember here that the concepts of 'folk poetry' and 'oral poetry' have often overlapped. For instance, the authoritative definition by Lord describes 'oral poetry' as "poetry composed in oral performance by people who cannot read or write. It is synonymous with traditional and folk poetry» (LORD, A. B.: The Princeton Encyclopedia of Poetry and Poetics. 1965, 591, s.v. 'oral poetry'). On orality and oral poetry, see e.g. FinNEGAN, R. H.: Oral Poetry: its Nature, Significance, and Social Context. Cambridge - New York 1977; FinnegAN, R. H.: Literacy and Orality: Studies in the Technology of Communication. Oxford - New York 1988; LORD, A. B.: Epic Singers and Oral Tradition. Ithaca - London 1991; LORD, A. B.: The Singer Resumes the Tale. Ithaca - London 1995. For orality in ancient Greek culture, crucial references can be found in ERCOLANI, A.: Defining the Indefinable: Greek Submerged Literature and Some Problems of Terminology. In COLESANTI-GiORdANO (n. 2) 718, here 13, n. 17; PALMiSCIANO (n. 2) 19, n. 1.

${ }^{12}$ Cf. PARKER (n. 9) 149f., n. 18.

13 YATROMANOLAKIS (n. 3) 264.

${ }^{14}$ See PALMisciano (n. 6) 154f., 167, n. 44; MAgNANi: Carmina (n. 6) 559-563.

15 See Neri (n. 5) 194f.; PALMisciano (n. 6) 154, n. 6; YATROMANOLAKIS (n. 3) 265; MAGNANI: Carmina (n. 6) 560f.; LELLI, E.: Folklore antico e moderno. Una proposta di ricerca sulla cultura popolare greca e romana. Pisa 2014, 29-31. 
in its parodic version Ar. Pax 796-801. A scholium to Aristophanes' passage glosses it as $\tau \grave{\alpha} \delta \eta \mu$ óía $\alpha \dot{\delta} \delta$ ó $\mu \varepsilon v \alpha$ and removes all doubt on its interpretation: $\delta \alpha \mu \omega ́ \mu \alpha \tau \alpha$ are the songs performed in public, as opposed to those composed for narrower ambits, such as the symposium. ${ }^{16}$ When Plutarchus, in his Life of Pericles (30. 4), defines

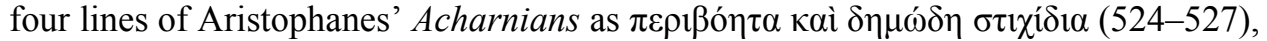
he is merely referring to the fame of those verses. Another example occurs in Plato's Phaedo (61a): for the philosopher there is a sharp distinction between $\mu$ оvбıкทे $\mu \varepsilon \gamma$ í-

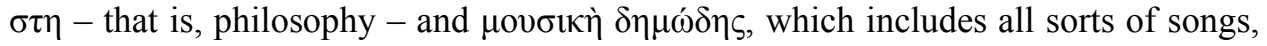
musical performances and poetry.

The fact that the notion of 'popular' remained untheorised in the ancient Greek world should not surprise us. Indeed, marked categories such as 'popular poetry', 'folk song' and 'folk culture' are all conceptualisations that have become current in literary criticism since the 18 th century and have been anachronistically related to ancient Greek literature only later. ${ }^{17}$ Hence, as mentioned above, the collection named Carmina popularia was created, albeit devoid of clear and well-defined criteria of composition.

We can in fact identify, among the songs of this corpus, a series of common features, which probably led to the creation of the corpus itself: anonymous authorship; oral composition, performance and transmission; textual fluidity (the so-called 'open tradition'); basic grammatical, lexical and syntactic structures; motley and frequently irregular metres and rhythms. ${ }^{18}$ Nevertheless, although these features could doubtlessly represent a precious starting point for interpreting and understanding ancient Greek folksong tradition as a whole, attention must be paid not to setting them as mere benchmarks. Otherwise, we would confine ourselves to studying sets of texts that are defined from the start as 'popular'. In this way, the corpus of Popularia would remain in its current state: a capacious, all-welcoming box into which all of the material that has not found its place within the 'official' and 'canonical' literature has been rudely thrust.

Let us return to the question posed at the beginning of this section: has ancient Greek popular poetry ever existed? Whatever answer will be given, we should bear well in mind that terms as 'folk' and 'popular' were entirely foreign to ancient Greek culture. If we want to apply them to the textual output of ancient Greece, we should be aware of the historical perspectives that those terms entail.

Over the last few decades, scholars have embraced other different approaches, which to some extent tackle the issue of ancient Greek folksong tradition. For instance, Neri suggests contrasting the Carmina popularia with the 'political' - i.e. related to the life of the polis - genres: e.g. epic, didactic poetry, lyric, tragedy, comedy, scientific, philosophical and historiographical prose. However, as the scholar acknowledges

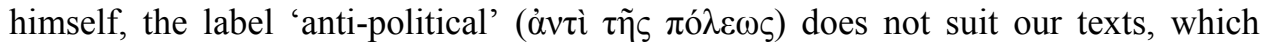
were integral part of the civic framework. Although they concerned minor aspects of

\footnotetext{
${ }^{16}$ Schol. ${ }^{\text {RVILh }}$ Ar. Pax 798 Holw.

${ }^{17}$ Cf. Neri (n. 5) 195; YATROMANOLAKIS (n. 3) 263f;; MAGNANI: Carmina (n. 6) 559-564.

${ }^{18}$ See Pordomingo (n. 6); NeRi (n. 5) 196-198; MAGNANI: Carmina (n. 6) 564f.
} 
the 'political' life, they were perfectly integrated into the festivals, rites and activities of the polis. ${ }^{19}$

A more prolific approach - and also more complex due to the variety of the subjects examined - is undoubtedly what stems from the observations of Rossi about the so-called 'submerged literature':

By 'submerged' literature I mean [...] texts which were mistreated from the very beginning of their transmission, and even texts which were not transmitted at all. These texts benefited of neither control nor protection, either because no community had any interest in their preservation, or because it was in the interest of a community that they be concealed, and even suppressed (as in the instance of everything that had to do with the mysteries). It is the case, however, that while a good deal of these texts have engaged us in a game of hide-and-seek, their part in shaping Greek culture as we know it was in fact considerable: there would be a great deal to gain if we could bring them back to light, although only parts of the whole may be recovered. For some time I have been thinking about the advantages of arranging these texts into a collection, which should display the (very few) fully preserved texts first, then the fragments, and finally the testimonia. The task would not be easy to accomplish, but deserves to be attempted. ${ }^{20}$

The scholar also lists a series of texts and of typologies of texts, which should feature in this supposed collection of 'submerged literature'. The seventh position is occupied by the very Carmina Popularia. ${ }^{21}$

A research group of Rossi's pupils has developed this project further, by coordinating a series of seminars (2011-2014) and publishing some of the results in a recent

${ }^{19}$ See Neri (n. 5) 198f. Cf. MAGNANI: Carmina (n. 6) 565.

${ }^{20}$ ERCOLANi (n. 11) 7. See ROSSI, L. E.: L'autore e il controllo del testo nel mondo antico. SemRom 3 (2000) 165-181, here 170: "Con letteratura 'sommersa' io intendo [...] testi maltrattati fin dal primissimo inizio della trasmissione, o anche testi che non hanno avuto alcuna trasmissione affatto. Questi testi non hanno goduto di alcun controllo e di alcuna protezione sia perché le varie comunità non avevano alcun interesse a conservarli sia perché avevano, piuttosto, interesse a nasconderli o addirittura a sopprimerli: quest'ultima categoria è rappresentata da quanto era legato ai misteri. Ma molti di questi testi, che dal nostro punto di osservazione giocano a nascondino, hanno avuto grande importanza nel configurare i vari momenti della cultura greca così come ci si presentano, ed è ovviamente nostro interesse cercare di rimetterli in luce, sia pure di necessità parzialmente. È per questo che da qualche tempo penso che sarebbe utile farne una raccolta, che dovrebbe configurarsi per testi integri (rari), per frammenti e infine per testimonianze. Non sarebbe un compito facile: ma varrebbe la pena affrontarlo." On the figure of Rossi as historian of literature, see NICOLAI, R.: Luigi Enrico Rossi storico della letteratura greca. Eikasmos 24 (2013) 367-406, esp. 371f.

${ }^{21}$ ROSSI (n. 20) 172: "Tutto quello che è compreso nella sezione Carmina popularia dei Poetae melici Graeci di Page, considerando che ci sono soltanto i frammenti di testo, mentre bisognerebbe integrare con titoli, testimonianze etc. Importanti i canti di lavoro, i lamenti funebri, i canti di nozze, tutti testimoniati fin da Omero." On the necessity of arranging a collection also of the testimonia, cf. MAGNANI: Carmina (n. 6) 570f.: the scholar calls for a census of some particular anonymous corpora, sporadically quoted by the sources. 
volume on this topic. ${ }^{22}$ Their inquiry aims to "understand what part of ancient Greek textual production became 'submerged', in what manner, and why",23 and, to this end, their approach privileges the 'context' of the textual production, that is to say the occasion and performance of texts themselves.

As it can be readily noted, more work remains to be done in advancing our understanding of what the texts collected in the Carmina popularia really were and meant in ancient Greek times. And in identifying methodological approaches that may take into account the variety and complexity of this particular typology of texts. For this purpose, I repeat, I am convinced that a new corpus of Popularia ${ }^{24}$ is needed.

\section{THE BEGGING SONGS}

Here is an example of what I have in mind when talking about a new corpus of Popularia. I would like to focus on the specific case of begging songs.

Begging songs belong to the European ethnographic heritage. They were mostly performed by groups of young people, who, either dressed up in costumes or not, or making use of extemporaneous totems or not, would on festive occasions ${ }^{25}$ go from home to home, asking for gifts such as food and drink. Scholars of folklore studies have formulated various hypotheses about the origin of begging songs, but they are generally traced back to the ancient seasonal rites of the rural world, which in both the pagan and Christian era often merged into the more traditional ritual calendar.

The ancient Greek sources hand us down five begging songs (see infra, App.): the chelidonisma or 'swallow song' (F 1), the koronisma or 'crow song' (F 2), the Samian eiresione (F 3), the Attic eiresione (F 4) and the song of Sicilian shepherds (F 5). ${ }^{26}$ These entire song-texts stem - more or less directly - from a common tradition,

${ }^{22}$ COLESANTI-GiORDANO (n. 2): the names of the scholars who have composed this research group are listed on p. 1 n. 4 . One of them, Palmisciano, came to propose a definition of 'popular' so as to be applied to ancient Greek literature (see infra, § 4).

${ }^{23}$ ERCOLANI (n. 11) 16.

${ }^{24}$ Even the definition of carmina can turn out ambiguous and misleading: cf. MAGNANI: Carmina (n. 6) 544 .

${ }^{25}$ See e.g. LEYDI, R. - MANTOVANI, S.: Dizionario della musica popolare europea, Milano 1970, 79-82 (s.v. 'Carol'), 180-185 (s.v. 'Maggio'), 211-213 (s.v. 'Canti di questua'); GRI, G. P.: Tradizioni popolari friulane nel Goriziano. In TASSIN, F. (ed.): Cultura friulana nel Goriziano. Gorizia 1988, 177190, here 178-184. In the field of classical studies, see ROBERTSON, N.: Greek Ritual Begging in Aid of Women's Fertility and Childbirth. TAPhA 113, 1983, 143-169. The scholar describes a series of female begging rituals associated with cults of different gods in different regions of Greece.

${ }^{26}$ The first and unique edition exclusively devoted to the begging songs is that of ILGEN (n. 4). Cf. later SCHÖNBERGER, O.: Griechische Heischelieder. Meisenheim a.G. 1980; LAMBIN (n. 6) 351-375; PALumbo StRACCA, B. M.: I canti di questua nella Grecia antica (I): il canto della rondine (PMG 848). RCCM 56.1 (2014) 57-78; PALUMBO STRACCA, B. M.: I canti di questua nella Grecia antica (II): Eiresione samia ed Eiresione attica. RCCM 56.2 (2014) 245-264. Schönberger and Lambin also include the pseudo-Homeric kaminos (Vit. Hom. Herod. 32. 433-461 All., Suda o 251 A.), which is, however, not regarded by them as a real begging song. On the kaminos, see MARKWALD, G.: Die homerischen Epigramme. Meisenheim a.G. - Königstein 1986, 219-244. Palumbo Stracca argues that the Attic eiresione cannot be considered a begging song. But hers is an argumentum ex silentio, on the basis of the text - which 
but only F 1 and F 5 have been included without exception in the corpora of Popularia. This is the risk we run if we apply the aforementioned blurred and ill-defined collection criteria too strictly. In fact using them excludes FF 2-4 from Page's edition $(P M G)$, given their authorial (or pseudo-authorial) character and/or their regular metrical form. Therefore, it is necessary to revisit these poems on the grounds of their common belonging to the begging tradition of ancient Greece.

The koronisma and the chelidonisma are transmitted in succession by Deipno-

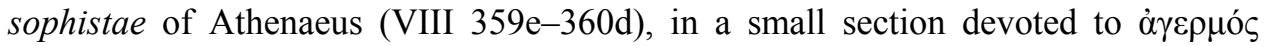
('begging') and the songs that accompanied it. Both texts represent a reworking of two ancient begging songs, handed down from generation to generation and performed on the occasion of special events.

As Theognis informs us, ${ }^{27}$ the chelidonisma was a song that accompanied traditional begging in Rhodes, called $\chi \varepsilon \lambda 1 \delta o v i \zeta \varepsilon ı v$ and was presumably performed by children (cf. 1. 20) to celebrate the arrival of spring (cf. 11. 1-5). ${ }^{28}$ This context of performance is confirmed by similar modern songs, stemming - more or less directly from the Greek text and still performed in some areas of Greece, during the Easter holidays or in spring. We can get a glimpse of the very similar opening lines of some chelidonismata collected by Passow:

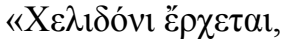

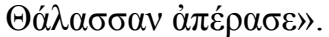

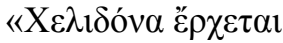

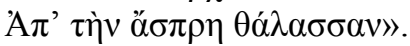

$$
\begin{aligned}
& \text { « } \mathrm{H} \rho \theta \varepsilon, \tilde{\eta} \rho \theta \varepsilon \chi \varepsilon \lambda 1 \delta \text { óv } \alpha \text {, } \\
& \text { ' } \mathrm{H} \rho \theta \varepsilon \kappa \mathrm{\varepsilon} \text { ' } \alpha \lambda \lambda \eta \mu \varepsilon \lambda \imath \eta \delta \text { óv } \alpha \gg .{ }^{29}
\end{aligned}
$$

may be fragmentary - and the testimonia, which may all stem from the same attidographic sources: cf. PALUMBO STRACCA: I canti II (n. 26) 259-262.

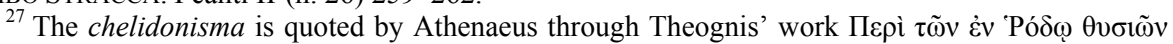
(FGrHist 526 F 1). See Morelli, G.: Un antico carme popolare rodiese. SIFC 35 (1963) 121-160, here

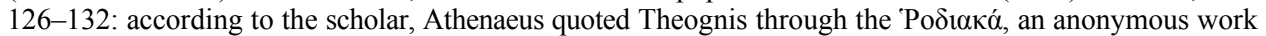

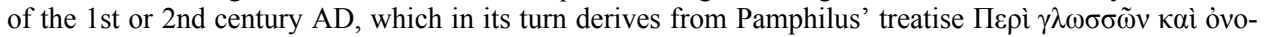

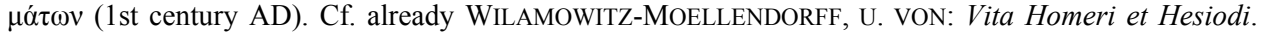
Bonn 1916, 57. It is without doubt hard to wholeheartedly endorse Morelli's reconstruction and assert

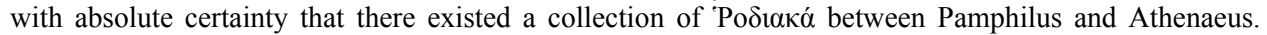
Notwithstanding this, it is quite sure that Athenaeus did not employ Theognis first-hand. It is more likely that he exploited, directly or not, Pamphilus' work. Cf. MAGNANI: Note marginali (n. 6) 51-53.

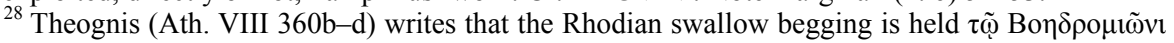
$\mu \eta v i ́$. However, according to most scholars, Theognis (or the manuscript tradition) wrongly substituted the Rhodian month Badromios (February-March) for the Attic form Boedromion (September-October): see SMYTH (n. 5) 507; EdMONDS (n. 5) 527, n. 2; Morelli (n. 27) 121f., n. 1; AdRAdOS, F. R.: La canción rodia de la golondrina y la cerámica de Tera. Emerita 42 (1974) 47-68 (=ADRADOS, F. R.: El mundo de la lírica griega antigua. Madrid 1981, 311-331), here 47, n. 1; DE STEFANI, C.: Fenice di Colofone fr. 2 Diehl $^{3}$. Introduzione, testo critico, comment. SCO 47.2 (2000) 81-121, here 83, n. 10; NERI (n. 5) 203. According to MAGNANI: Note marginali (n. 6) 53-56, this misunderstanding in Athenaeus or in his source may bring us even closer to the origin of the written tradition of the poem.

${ }^{29}$ PAssow, A.: Popularia carmina Graeciae recentioris. Lipsiae 1860, 225-227 nos. 305, 307

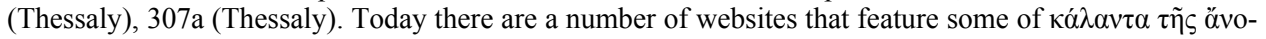
$1 \xi \eta \varsigma$ ('spring carols'), categorised by regions and cities of Greece: see e.g. <http://amplokaristes.blogspot.it/ 
As regards the koronisma, the context in which it was performed is a matter of debate. Neither the ancient sources nor the comparisons with modern folksong tradition can help us with this issue. In general, the koronisma is regarded as the autumnal or winter equivalent of the chelidonisma. ${ }^{30}$

It may also be remembered that the swallow and the crow, in whose honour songs were performed, were ostensibly represented through a stylized disguise, or a notched (maybe painted) wood totem of the same bird. ${ }^{31}$ In this regard, I may refer to a video, ${ }^{32}$ in it, a cortège of men and boys from Neochori ${ }^{33}$ perform the кá $\lambda \alpha v \tau \alpha \tau \tilde{\eta} \varsigma$

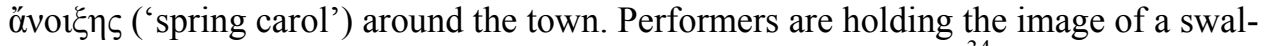
low that they spin with a piece of string not unlike a spinning top. ${ }^{34}$

In the light of these considerations, both the chelidonisma and the koronisma appear to be part of the folkloric heritage of ancient Greece. However, the koronisma has been systematically excluded from the various collections of the Carmina popularia, because of its authorial character and its regular metre. It was composed by Phoenix of Colophon ${ }^{35}$ in choliambs and therefore ascribed to the Hellenistic iambic production. On the contrary, the chelidonisma, which is an anonymous poem written in aeolic-choriambic and iambic metres, has appeared under that label since the earliest editions of Greek lyrics. It is legitimate to wonder how valid this exclusion is.

According to Theognis, the swallow song was strictly related to the begging that happened in Rhodes. Cleobulus first introduced this practice in Lindos, "when

2011/04/blog-post.html> [30. 11. 2014]. On these modern songs and related bibliography, see SMYTH (n. 5) 507f.; CESSI, C.: Storia della letteratura greca dalle origini all'età di Giustiniano. Torino 1933, 491f.; JACOB, O.: Le chant populaire des Rhodiens: le retour de l'Hirondelle. LEC 6 (1937) 232-246, here 242246; THOMPson, D'A. W.: A Glossary of Greek Birds. London-Oxford 1936, 320; SCHÖNBERGER (n. 26) 64-74; CAMPBell, D. A.: Greek Lyric Poetry. Bristol $1982^{2}$ (1967¹), 446f.; LAMBIN (n. 6) 365; MAGNANI: Carmina (n. 6) 572f.

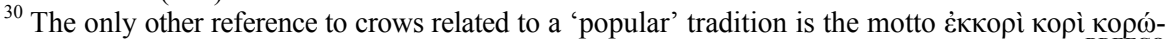

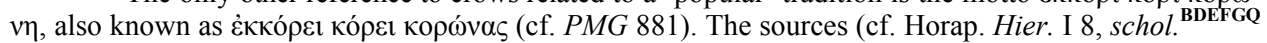
Pind. $P$. 3,32c Drachm.) regarded it as a nuptial refrain: the crow, indeed, is the symbol of marital fidelity and harmony (see also Aelian. NA III 9). Perhaps, the koronisma was intoned on the occasion of wedding rites. On PMG 881 and its interpretations, see CERRATO (n. 6) 237-242; RIESS, E.: The Crow. Classical Weekly 37 (1943/1944) 178f.; MiRAlles, C.: Carmina popularia fr. 35 Page. Faventia 3.1 (1981) 89-96; LAMBIN (n. 6) 86-92, 104; PORDOMINGO (n. 6) 468, 471, 478; DE STEFANI (n. 28) 88; NeRI (n. 5) $249-251$.

${ }^{31}$ Cf. Cerrato (n. 6) 326; SMYth (n. 5) 507; JACOB (n. 29) 233; Adrados (n. 28) 52; SNELl, B. - Franyo, Z.: Frühgriechische Lyriker. Vol. I-IV (Die Chorlyriker). Berlin 1971-1976, IV 107; WeSt, M. L.: Greek Lyric Poetry. Oxford 1993, 212.

${ }^{32} \mathrm{https}: / /$ www.youtube.com/watch?v=t8hBo40J3qs [20. 06. 2015]

33 A village on the peninsula of Pelion, Magnesia, eastern Thessaly, Greece.

${ }^{34}$ In modern begging traditions some people also employ a captured, slaughtered and impaled animal as described by Burkert: "In Wales and Ireland a wren was hunted, killed, and carried on a stick by a procession of singing boys who proceeded to beg for money and food for an evening feast right on Christmas Day" (BURKERT, W.: Structure and History in Greek Mythology and Ritual. Berkeley - Los Angeles London 1979, 137).

${ }^{35}$ Phoenix of Colophon lived in the 3rd century BC and was the author of two books of iambi. Only about eighty lines have been preserved. For an overview of this poet, see recently DE STEFANI (n. 28) $81 \mathrm{f}$.

${ }^{36}$ Cleobulus was one of the Seven Sages and the tyrant of Lindos for forty years. His akmé dates from 628-625 BC (see M. G. ALBIANI in NP VI (1999) 576, s.v. 'Kleobulos' 1); A. MARCHIORI in CANFORA, L. (ed.): Ateneo. I deipnosofisti. I dotti a banchetto. Vol. I-IV. Roma 2001, II 897f., n. 5). 
there was need in that city of a collection of money". Taken at face value, this account implies that the tyrant of Lindos reinvented the ancient propitiatory rite connected with the arrival of spring - maybe widespread in other areas of the island as well as of the entire Greek world - for the purpose of a 'daring economic policy'. 37 This information, however, may well be unreliable. Indeed, it is now common knowledge that witnesses may be biased and their claims often completely baseless, when they state that an illustrious character, such as Cleobulus, 'invented' a particular tradition, especially a literary one. ${ }^{38}$ It therefore seems unwise to say, on the basis of this anecdote, that Athenaeus' version reproduces the chelidonisma as it was really composed and diffused in Rhodes at the time of Cleobulus (7th/6th century BC): it would be like believing in the authenticity of the maxims of the Seven Wise Men.

To refute Theognis' autoschediasmos does not mean to deny the Rhodian origin of the chelidonisma quoted in Deipnosophistae. Or rather, it is most plausible that the song in its turn stemmed from an ancient tradition, maybe even earlier than the 7 th century $\mathrm{BC}$ and widespread well beyond the boundaries of Rhodes itself. However, assigning a precise date to it is an arduous task. ${ }^{39}$ Nor is it possible to obtain a linguistic as well as a metrical uniformity. ${ }^{40}$

Therefore, I believe that a conservative approach should be adopted when constituting the text of the chelidonisma. The aim here should not be to restore the chelidonisma sung by children of Rhodes around the end of the 7th century BC, but more realistically to edit the song that Athenaeus and his source knew.

As a result, the metrical structure of the chelidonisma appears to be based on simple and basic rhythms. Aeolic-choriambic sequences (cf. 11. 1-13) and iambic cola (cf. 11. 14-20) are, indeed, recurring rhythms of ritual songs. ${ }^{41}$ The traditional and archaic character of the poem is also confirmed by the paratactic construction, elliptical expressions, figures of iterations and syntactical and grammatical parallelisms.

On the other hand, the poem's language seems to betray a varied and more 'literary' nature: the conservation of $-\bar{\alpha}(-)$ (cf. $11.4,6,15,16,19)$, the presence of the

${ }^{37}$ Cf. NERI (n. 5) 201.

${ }^{38}$ It is typical of Greeks «to fabricate authors for the adesposta: Eriphanis and Kleobulos were made the originators of songs that are truly anonymous» (SMYTH [n. 5] 491). Most scholars, therefore, do not trust Theognis' information: cf. ADRADOS (n. 28) 64; CERRATO (n. 6) 323; SMYTH (n. 5) 508; CESSI (n. 29) 490, n. 26; CAMPBELL (n. 29) 446; LAMBIN (n. 6) 363; YATROMANOLAKIS (n. 3) 268. On Eriphanis' song (PMG 850) see LAMBIN (n. 6) 38-52; PORDOMINGO (n. 6) 464; NERI (n. 5) 205-207.

${ }^{39}$ The chronological interpretation accepted by most scholars is that of Ahrens, which traces the chelidonisma back to the time «qua genuina Rhodiorum Doris Atthide temperari coepta erat», i.e. the 5th and 4th centuries BC (AHRENS, H. L.: De Graecae linguae dialectis. Vol. I-II. Gottingae 1839-1843, II 479). Similarly PAGE (n. 5) 451: "est chelidonismi forma recentior: vetustiorem Rhodiorum dialectum aliquatenus restituere possis". ADRADOS (n. 28) 64 does not exclude an earlier dating, provided it is not beyond the 7th century BC. Cf. MAGNANI: Carmina (n. 6) 556.

${ }^{40}$ Cf. NeRI (n. 5) 204: "Priscam carminis dialectum metricamque rationem restituere frustra conaberis, ubi aetatum gentiumque vestigia variorum inveneris." For an overview of the metric and linguistic issues (with the different approaches adopted by editors), see MAGNANI: Carmina (n. 6) 549f. and 555-558, respectively.

${ }^{41}$ Cf. WEST, M. L.: Greek Metre. Oxford 1982, 146-149; MARTINELLI, M. G.: Gli strumenti del poeta. Elementi di metrica greca. Bologna 1995, 192, 253f. See also PORDOMINGO (n. 6) 473. 
Ionism/epicism $\mu \mathrm{v} v$ (1. 17), the verbal endings in - $\mu \varepsilon \varsigma$ (11. 13 and 15) and the aforementioned genitive $\tau$ ary Doric of Hellenistic age (similar to that of Theocritus and Callimachus).

Therefore, it is not far-fetched to assume that the chelidonisma, as known to Theognis and transmitted by Athenaeus, is a 'literary' version or - at least - one of the first written versions, probably dating from the 3 rd or the 2 nd century BC, of an ancient and traditional song. ${ }^{42}$ It is no surprise that the original chelidonisma was reworked and adapted to literary use during the Hellenistic age. Indeed, in this period the erudite passion of Alexandrian poets for folklore and local mores, as well as for the literary recycling of ritual and traditional materials, was widespread. ${ }^{43}$ Another example is Phoenix's koronisma.

The koronisma displays the typical mechanisms of beggars: minimal requests; blessings for whosoever donates something; veiled threats of jinx for those who do not satisfy the beggars' demands; asking for charity as payment for the musical entertainment provided. The main purpose of Phoenix's poem was to rework in literary terms a song performed in the begging tradition. ${ }^{44}$ This same operation has been identified in the chelidonisma, although in the koronisma the poetic element is more defined. This may be noticed, for example, in the use of the choliamb and in the literary Ionic language.

Analogous considerations can be made for the two eiresionai. On 1st May, at Abingdon near Oxford, young people used to intone the following chant:

"We've been rambling all the night,

And sometime of this day;

And now returning back again,

We bring a garland gay.

A garland gay we bring you here;

And at your door we stand;

It is a sprout well budded out,

The work of our Lord's hand". 45

\footnotetext{
${ }^{42}$ The chelidonisma cannot be assumed to belong to a purely oral tradition. Nor, in the same way, may we assert that this text stems from a well-established written literary tradition. Nevertheless, we are now aware that there are many degrees between those extremes. Indeed, when an oral song is written down, it may be subject to more or less radical changes in its style, its structure and/or its rhythm. For example, LORD: The Singer (n. 11) 22 talks about a "scale of pure oral tradition $\rightarrow$ transitional stages $\rightarrow$ written tradition". On the concept of 'transitional text', see ibid. 212-237 (cf. also 16-19). Unfortunately, on the basis of the data we have, it is impossible to state how much distance occurs between the 'original' version of the chelidonisma and its literary or semi-literary fixed form. Similarly, we are not able to tell how much influence this written version had on the later oral tradition. On the influence of a fixed text, see LORD: Epic Singers (n. 11) 170-185.

${ }^{43}$ Cf. De Stefani (n. 28) 92; MAGNANi: Carmina (n. 6) 571.

${ }^{44}$ The literary character of the koronisma brought about interpretations that do not take into account the general structure of the poem and consequently regard it as something more than just a poetic version of a begging song. Cf. GERHARD, G. A.: Phoinix von Kolophon. Leipzig-Berlin 1909, 179-181;

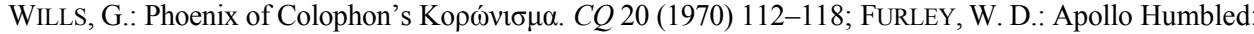
Phoenix' Koronisma in Its Hellenistic Literary Setting. MD 33 (1994) 9-31.

${ }^{45}$ Frazer, J. G.: The Golden Bough. A Study in Magic and Religion. London $1923^{2}\left(1922^{1}\right), 121$.
} 
The examples of chants such as this are unlimited. They are part of ancient pagan traditions of vegetable and plant worship that still survive in some rural pockets of modern Europe. One well-known example is the 'May tree' or the 'May pole'. It was the tradition of European peasants during traditional festivals to hold high a branch or a tree so as to bring home to each village the blessing that only the tree spirit was able to bestow. ${ }^{46}$

Such propitiatory rituals were also widespread in the Greek world: one of these

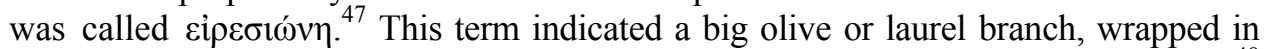
wool (possibly white and purple-stained) bandages and laden with all sorts of fruits. ${ }^{48}$

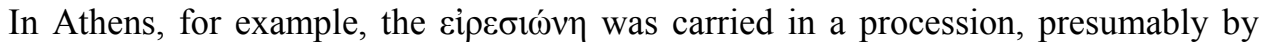
boys, at the Pyanepsia in honour of Apollo, to whom it was then offered. On that occasion, twigs were also fastened on the door of every house as a good omen - like the surviving custom to hang up a twig of mistletoe in houses - and were annually burned and replaced with new samples. In addition, and more pertinently, while carrying the May tree was accompanied by chants, so too the ancient Greeks used to perform traditional songs during the ritual of eiresione. There are two songs of this type handed down to us: the so-called Samian eiresione and the Attic eiresione.

The former is part of the fifteen epigrams attributed to Homer and is contained in the pseudo-Herodotean Life of Homer (33. 467-480 All.), whereas the latter eiresione is cited by a number of witnesses (twelve in all) ranging from Plutarchus' Lives

${ }^{46}$ Cf. FRAZER (n. 45) 120: "In spring or early summer or even on Midsummer Day, it was and still is in many parts of Europe the custom to go out to the woods, cut down a tree and bring it into the village, where it is set up amid general rejoicings; or the people cut branches in the woods, and fasten them on every house. The intention of these customs is to bring home to the village, and to each house, the blessings which the tree-spirit has in its power to bestow. Hence the custom in some places of planting a May-tree before every house, or of carrying the village May-tree from door to door, that every household may receive its share of the blessing." Vestiges of these ancient rituals are surely the greasy pole, a traditional fiesta game, and the Christmas tree (albeit the latter in a different season of the year). On tree worship and related rites, see MANNHARDT, W.: Wald- und Feldkulte. Vol. I-II. Berlin 1904-1905 ${ }^{2}$ (1875-1877 ) I; LEYDI-MANTOVANI (n. 25) 180-185; FRAZER (n. 45) 120-135.

${ }^{47}$ For the sources on the ritual of eiresione, cf. testimonia in $\mathrm{F} 3$ as well as Ar. Eq. 728f., $\mathrm{Pl}$.

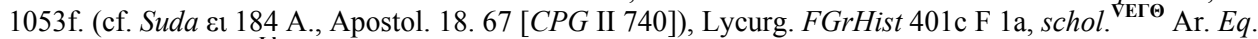
729a (II) M.J., schol. ${ }^{\text {Lh }}$ Ar. Eq. 729d M.J., schol. Ar. Pl. 1054a-d Ch., Suda $\delta 589$ A., Lact. Plac. Comm. in Stat. Theb. II 737-738, XII 492 Sweeney. Other similar rituals were practiced throughout Greece, such

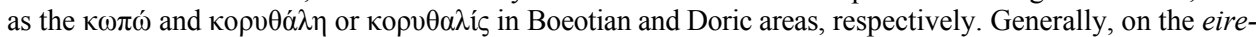
sione, kopo and korythale see ILGEN (n. 4) 134-164; MANNHARDT (n. 46) II 214-253 (in particular, on the Samian eiresione 243-248); NILSSON, M. P.: Griechische Feste von religiöser Bedeutung: mit Ausschluss der Attischen. Leipzig 1906, 116-118, 164-166, 182-189; PESTALOZZA, U.: Le thargelie ateniesi. SMSR 6 (1930) 232-272, here 233-251; CESSI (n. 29) 483-487; DEuBnER, L.: Attische Feste. Berlin 1932, 198-204; FolLET, S.: Deux vocables religieux rares attestés épigraphiquement. $R P h 48$ (1974) 3034, here 30-32; SCHÖNBERGER (n. 26) 26-42; BURKERT (n. 34) 134-138; LAMBIN (n. 6) 354-361; GIANOTTI, G. F.: Storie di calendario: il tempo festive. SLGA III (1996) 162-164.

${ }^{48}$ On the various interpretations of the etymology of the term, see CHANTRAINE, P.: La formation

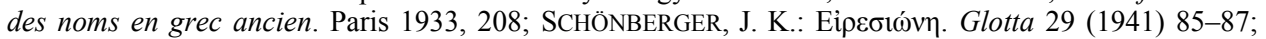
GroŠElJ, M.: Etyma Graeca. ZAnt 1 (1951) 121-131, here 122f.; P. ChANTRAINE in DELG 324, s.v.

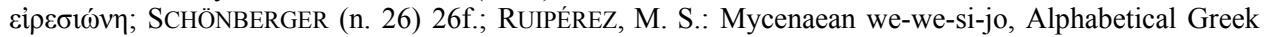

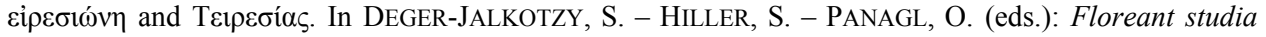
Mycenaea. Akten des 10. Internationalen Mykenologischen Colloquiums in Salzburg vom 1.-5. Mai 1995. Vol. I-II. Wien 1999, II 537-542. 
(1st or 2nd century) to the Collections of Proverbs by Michael Apostolius (15th century). $^{49}$

In the Samian eiresione, a mocking and threatening tone can be detected similar to what occurs in the chelidonisma, which is underscored by a comparable metrical structure. On one hand, the chelidonisma shows a succession of aeolic-choriambic sequences and iambic trimeters - as I have mentioned above, typically ritual rhythms. On the other hand, in the Samian eiresione, the analogous minatory $\pi \alpha \rho \alpha \kappa \alpha \tau \alpha \lambda \circ \gamma \eta$ in iambic metre is preceded by a series of hexameters, which represent both the metre of the literary reference model (Homer), and "the oldest and the most folkloric of metres". 50

The formal structure of the Samian eiresione also bears a striking resemblance to that of the koronisma. In the same way, it starts off with blandishments towards the landlord, proceeds with a series of blessings for the whole family, in particular, wishes for wedded bliss, and concludes with the insistent requests from the beggars. ${ }^{51}$

It can be therefore inferred that the Samian eiresione is part of the tradition of begging songs, handed down through the literary channel, such as in the case of the chelidonisma and the koronisma. However, like the koronisma, it has been excluded from the Carmina popularia, because of its higher poetic level and/or its attribution to Homer.

The Attic eiresione did not share a better fate. Although it is impossible to clarify the exact origin of the refrain - which could either be entirely 'popular', belong to the literary channel or be mediated by the latter - the attic eiresione is without a doubt a traditional song. Nevertheless, it has been omitted from most editions of the Carmina popularia, ${ }^{52}$ on the basis of the argumentations of Bergk, who dealt with the Attic refrain separately due to its metrical uniformity. ${ }^{53}$ Again, this exclusion seems to be not only unjustified but also contradictory, if we think of the hexameter as the metre of tradition par excellence and the favourite medium for oracular sentences, riddles, rigmaroles and magic formulae. ${ }^{54}$

There is another song requiring our analysis: the so-called Siculorum mendica cantilena (F 5). Like the chelidonisma, it appears in the main editions of the Carmina popularia. In brief, this Sicilian refrain comes down to us through the scholiographic

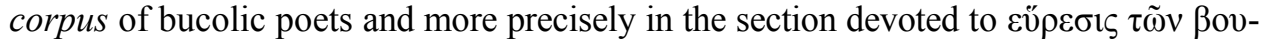
$\kappa о \lambda \iota \kappa \tilde{\omega}$ (Proleg. Theocr. B Wend.). This is a short treatise on the origin of bucolic poetry, ${ }^{55}$ which provides three etiological anecdotes on the subject. According to the third (cf. Proleg. Theocr. Ba 2. 21 - Bb 3. 15 Wend.), bucolic poetry first appeared

${ }^{49} \mathrm{Cf}$. the testimonia in $\mathrm{F} 4$.

${ }^{50}$ FURLEY (n. 44) 16; cf. n. 21.

${ }^{51}$ On the similarities between the Samian eiresione and the two bird songs, cf. MARKWALD (n. 26) $251 f$.

${ }_{53}^{52}$ With the exceptions of DieHL (n. 5) (Carm. pop. 2) and EDMONDS (n. 5) (Carm. pop. 17).

53 "Porro omnia, quae heroicis versibus composita sunt, procul habui. Seiungenda igitur cantilena

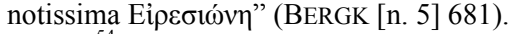

${ }_{55}^{54}$ Cf. WEST: Greek Metre (n. 41) 35.

${ }^{55}$ On this treatise, see BERNASCONI, A.: Un trattatello sull'origine della poesia bucolica ( $S c h$. in Theocr. vet. prol. B): AAntHung 50.1 (2010) 27-62. 
in Syracuse, when, after an episode of bloody civil strife, the citizens celebrated the goddess Artemis, as she was believed to have re-established peace and harmony. The celebration was conducted with songs and gifts that became part of a traditional ritual. ${ }^{56}$ From that time onwards singing contests were held during the festivals in honour of Artemis: the winners received the loaf carried by the defeated antagonists and were able to remain in Syracuse; the losers had to roam from village to village begging for charity and singing entertaining and blessing-filled songs in return.

To sum up, all the songs we have looked at so far demonstrate that the begging tradition has its roots in ancient propitiatory rituals. These were then merged and institutionalised into more or less official celebrations. Ancient Greeks (mostly children and young people) usually sang these songs and chants for the purpose of collecting small gifts (generally food or drink), in exchange for prosperity and wealth.

The texts, especially the longer ones (FF 1-3), reveal a similar structure characterized by four essential features:

- The captatio benevolentiae addressed to landlords (cf. e.g. FF 1. 6-9; 2. 1, 4, 18; 3. 1f.);

- Blessings for the whole family (cf. e.g. FF 2. 10-14; 3. 8-10; 5. 1f.);

- Demands for gifts (cf. e.g. FF 1.6-12; 2. 1-7);

- Joking threats in case of refusal (cf. e.g. FF 1. 13-18; 3. 14f.). ${ }^{57}$

Other recurring themes stand out. These include the topos of the god غ̇ंowíílos (cf. FF 2. 8; 3. 3-5; 5. 1f.) $)^{58}$ and the formulaic expressions beggars employ to get people to open their front doors (cf. FF $1.19 ; 2.8 ; 3.3$ ) or menacingly ask for offers: cf. FF 1 . $14 ; 3.14$. In these last two passages, the same two ellipses are found: a lack of apodosis in the first conditional sentence and no verb in the protasis of the following conditional sentence. The general meaning is: "if you give us something, that's fine and we will go away; if you don't, we won't leave you in peace / we shall not stay". 59

\footnotetext{
${ }^{56}$ On the Syracusan ritual, see Frontisi-DuCrouX, F.: Artémis bucolique. RHR 198 (1981) 2956; Frontisi-DucrouX, F.: L'homme, le cerf et le berger. Chemins grecs de la civilité. TR 4 (1983) 5376; LAMBIN (n. 6) 352-354.

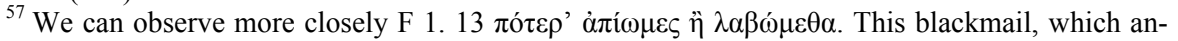
nounces the far more explicit threats that follow, has an equivalent in the modern motto 'Trick or treat?' - the slogan chanted by children who call at houses to solicit gifts at Halloween. Cf. CAMPBELL (n. 29) 446f.

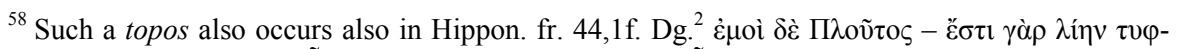

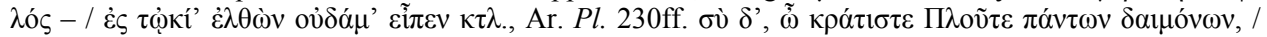

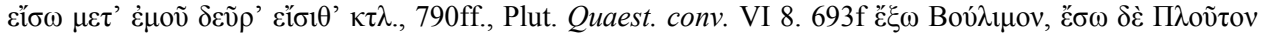

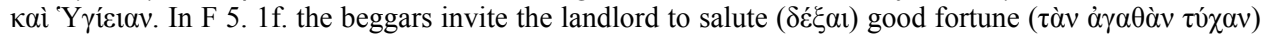
and health $(\tau \dot{\alpha} v$ vofíciav). However, in this case the two terms might also indicate well-being and the re-

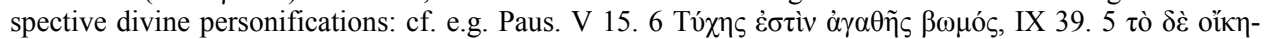

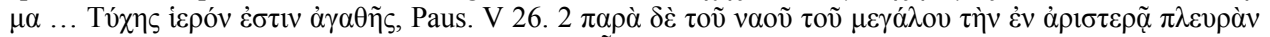

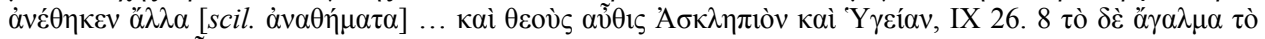

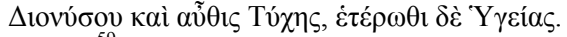

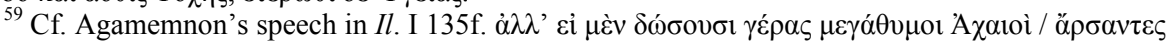

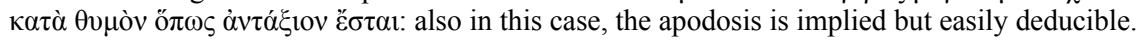


In addition, we can have a look at another pattern, which occurs in F 1.1 and F 3. 11. The first section of the chelidonisma (11. 1-5) is devoted to the arrival of the swallow: the bird that, already for the ancient Greeks, was the emblem of returning spring. ${ }^{60}$ The incipit $\tilde{\eta} \lambda \theta^{\prime}, \tilde{\eta} \lambda \theta \varepsilon \chi \varepsilon \lambda \iota \delta \omega$, still retained in the modern carols with the

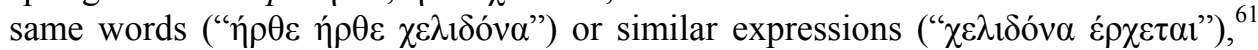
immediately makes such an image vivid. Indeed, the repetition of the verb assumes a plain literary and rhythmical function: it stresses the cyclical return of the swallow. ${ }^{62}$ In the case of the Samian eiresione, the reference to the opening words of the chelidonisma (11. 1-3) is apparent. It is a reference that is highlighted by the syntactic structure, with the analogous repetition of the main verb: the eiresione or, even better, its personified spirit, will cyclically return just like the swallow in spring and, just like the arrival of the swallow, the arrival of the tree spirit represents a sort of New Year's Day blessing. ${ }^{63}$

\section{FINAL REMARK}

In the current state of research and studies, the need to review the reference corpus in terms of both omissions and additions is apparent. ${ }^{64}$ This should be based on an exhaustive census of texts which have as yet not been taken into account (e.g. 'the songs of sailors', P. Oxy. 425, 1383), or which have not been included intentionally in the sylloge by earlier editors. Furthermore, more work remains to be done in defining the concept of 'popular' in the ancient Greek world.

It is hard to deny that in the 21 st century, ancient Greek folksong tradition still requires the detailed attention of scholars and experts. ${ }^{65}$

\section{APPENDIX}

F 1

Edd.: Ath. VIII 360b-d. Carm. pop. 2 Neri $=848$ Campbell $^{1}=P M G 848=20$ Edmonds $=32$ Diehl $=22$ Smyth $=41$ Bergk $^{3,4}=29$ Bergk $^{2}=17$ Bergk $^{1}=32$ Schnei- $^{2}$ dewin.

Testt.: (I) Ath. VIII 360b-d, (II) Eust. Od. 1914. 45-53 St. Cf. Hesych. $\chi 324$ Cunn.

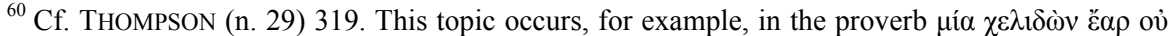
$\pi$ oteĩ, from which the equivalent proverb of the modern languages derives (cf. R. TOSI in DSLG 549f.).

${ }^{61}$ Cf. supra, $\S 3$.

${ }^{62}$ Cf. PORDOMINGO (n. 6) 472.

${ }^{63} \mathrm{Cf}$. also Ar. $A v .679 \tilde{\eta} \lambda \lambda \varepsilon \varsigma, \tilde{\tilde{\eta}} \lambda \theta \varepsilon \varsigma, \ddot{\omega} \varphi \theta \eta \varsigma$. In Aristophanes' passage the similarity is due not only to the use of the same verb as in the chelidonisma, but also because the verb repetition emphasises the emotional connection with the interlocutor. It is not excluded that this passage could have directly been influenced by the text of the chelidonisma: cf. MAGNANI: Note marginali (n. 6) 54.

${ }^{64}$ Cf. MAGNANI: Carmina (n. 6) 570.

${ }^{65}$ Cf. Rossi, L. E.: Letteratura greca. Firenze 1995, 192.
} 
(N) $\tilde{\eta} \lambda \theta^{\prime}, \tilde{\eta} \lambda \theta \varepsilon \chi \varepsilon \lambda 1 \delta \grave{\omega} v$

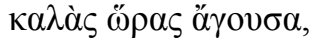

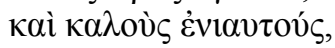

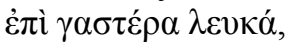

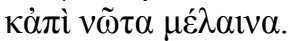

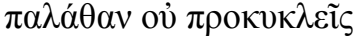

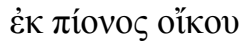

oúvov $\tau \varepsilon \delta \dot{\varepsilon} \pi \alpha \sigma \tau \rho o v$

$\tau \nu \rho \tilde{\omega} \tau \varepsilon \kappa \alpha ́ v v \sigma \tau \rho o v$;

$\dagger \kappa \alpha \grave{~} \pi v \rho \tilde{\omega} v \alpha \dagger \chi \varepsilon \lambda 1 \delta \omega े v$

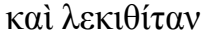

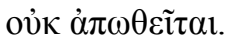

$\pi$ ó $\varepsilon \varepsilon \rho$ ' $\alpha \pi^{\prime} \omega \mu \varepsilon \varsigma$ ì $\lambda \alpha \beta \omega ́ \mu \varepsilon \theta \alpha$;

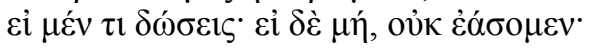

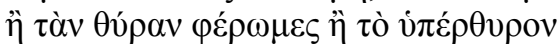

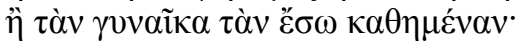

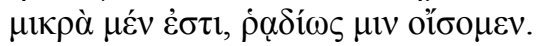

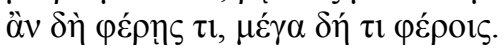

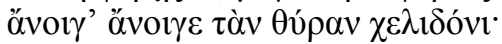

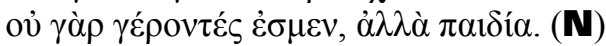

Metr.: 11. 1, 4, 7-9 reiziana (rei: b I kkl uU; 11. 2, 3, 5 pherecrateans (pher: xxl kkl uU; 1. 6 acephalic choriambic dimeter $\left(2 \mathrm{cho}^{\mathrm{B}}: \mathrm{xxXl}\right.$ uW U; 1.10 corrupt (reizianum or pherecratean?); 1.11 adonean (ad: I un uU); 1.12 hypodochmium (h $\delta$ : I w I uU); 1.13 acephalic reizianum (o adonean) + hypodochmium

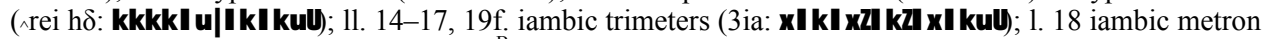
+ acephalic choriambic dimeter (ia $\wedge 2 \mathrm{cho}^{\mathrm{B}}: \mathrm{kl} \mathrm{ku} \mid \mathrm{xxXl}$ und U.

Codd.: ACE (I) - M (II).

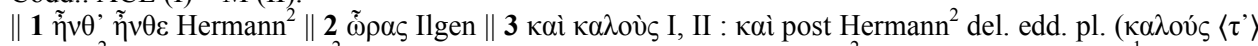

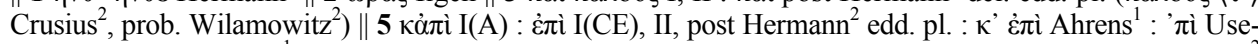

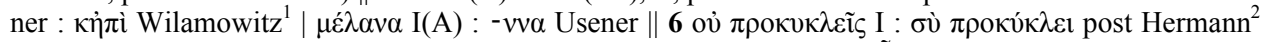

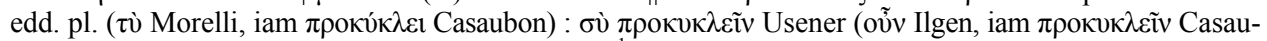

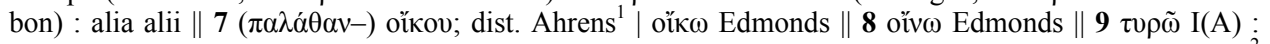

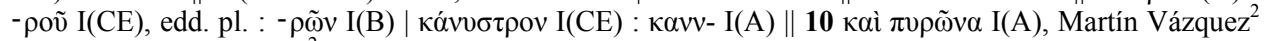

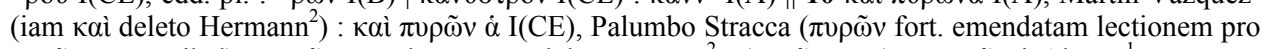

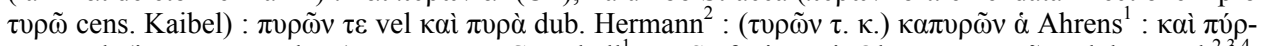
$v \alpha$ Bergk (iam $\pi v ́ \rho v \omega v$ Ilgen), recc. Page, Campbell ${ }^{1}$, De Stefani, Neri, Olson : $\kappa \alpha \tau \nu \rho \tilde{\omega} v \alpha$ dub. Bergk ${ }^{2,3,4}$,

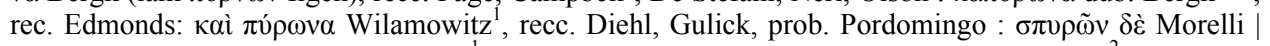

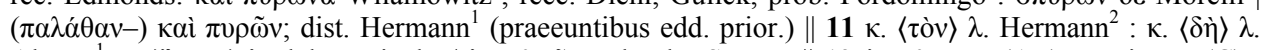

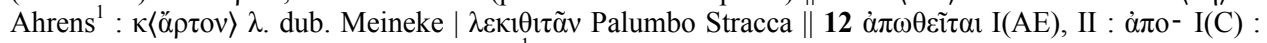

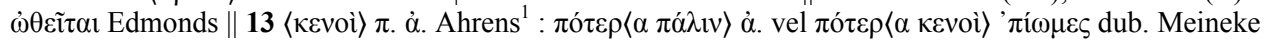

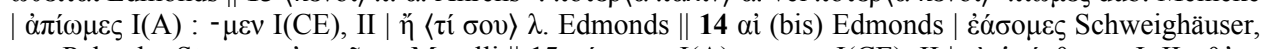

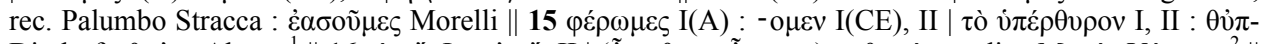

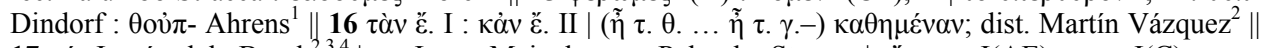
$17 \mu \varepsilon \dot{v} \mathrm{I}:$;ó $\rho$ dub. Bergk ${ }^{2,3,4} \mid \mu \mathrm{I}$ I : viv Meineke, rec. Palumbo Stracca $\mid$ ő̋ $\sigma o \mu \varepsilon v \mathrm{I}(\mathrm{AE}):-\mu \alpha \mathrm{I}(\mathrm{C}):-\mu \varepsilon \varsigma$

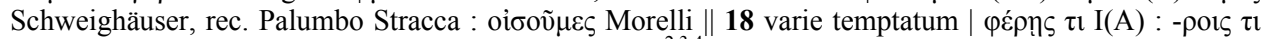

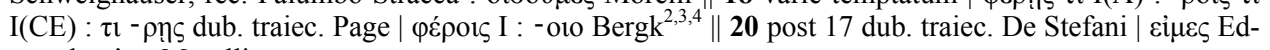
monds : $\dot{\varepsilon} \sigma-$ Morelli.

\section{$F 2$}

Edd.: Ath. VIII 359e-360b. Phoen. fr. 2 D. ${ }^{3}=2$ Knox $=2$ Powell $=1$ Schneidewin. Test.: Ath. VIII 359e-360b. Cf. Hesych. $\kappa 3748$ L., Eust. Od. 1914,49s. St. 


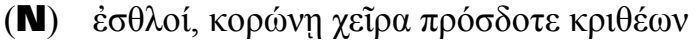

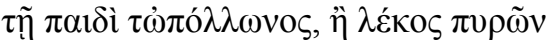

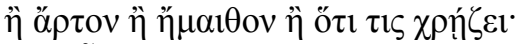

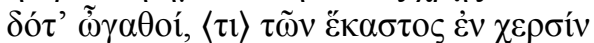

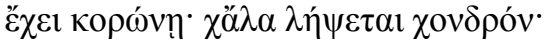

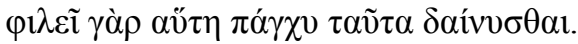

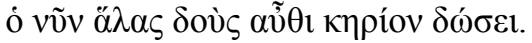

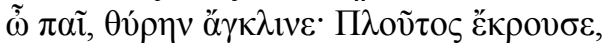

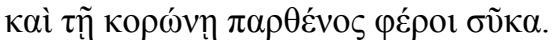

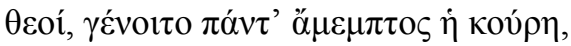

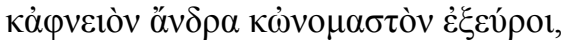

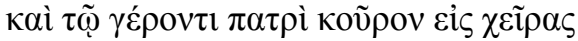

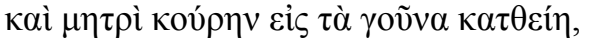

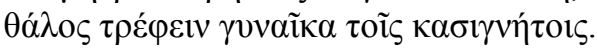

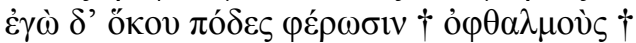

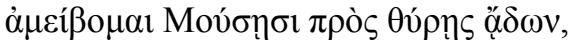

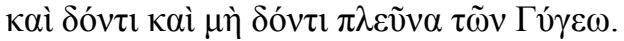

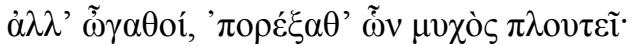

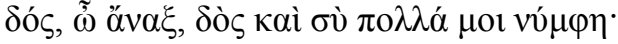

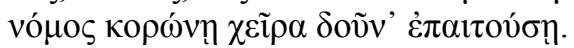

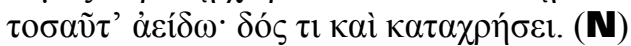

Metr.: choliambs (chol: Xl kl xZ्Z kZZ kl I uU).

Codd.: ACE.

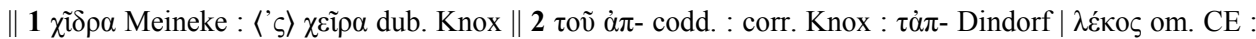

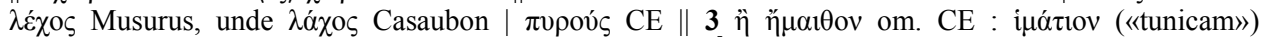

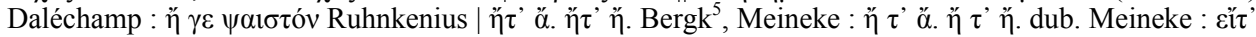

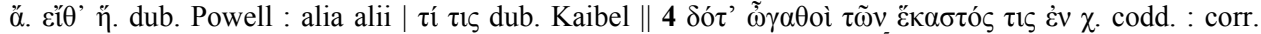

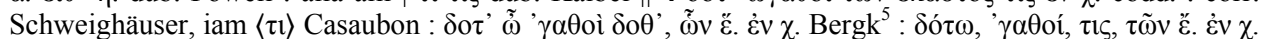

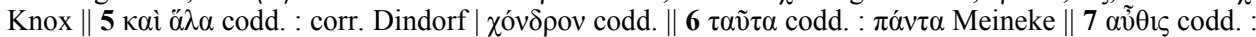

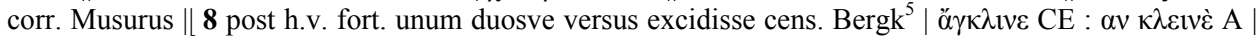

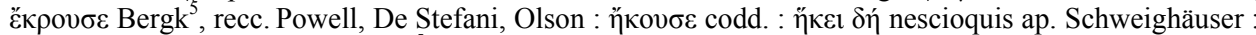

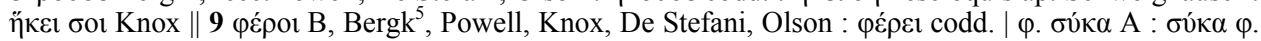

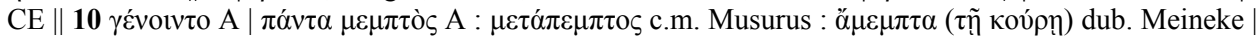

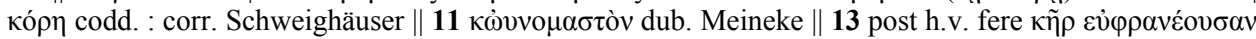

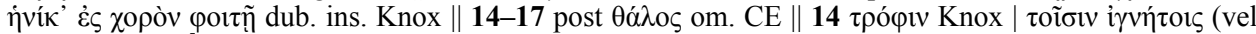

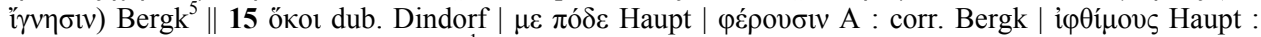

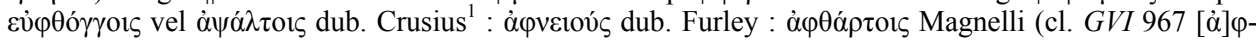

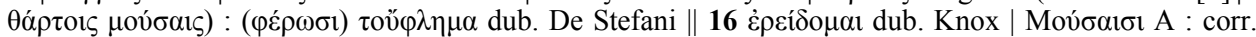

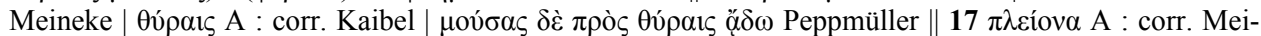

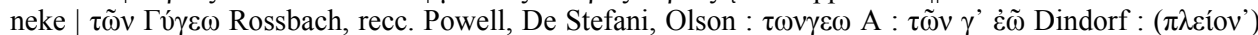

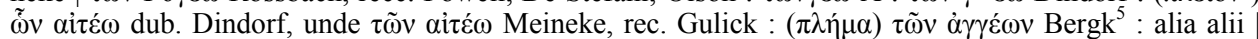
post h.v. desunt nonnulli versus $\| \mathbf{1 8 - 2 0}$ post 7 traiec. Peppmüller $\| \mathbf{1 8} \dot{\varepsilon} \pi \circ \rho \varepsilon \dot{\xi} \xi \alpha \theta^{\prime}$ codd. (- $\left.\tau \varepsilon \mathrm{CE}\right)$ : corr.

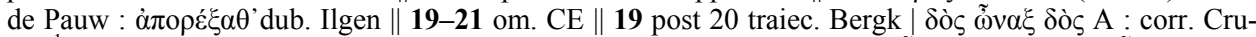

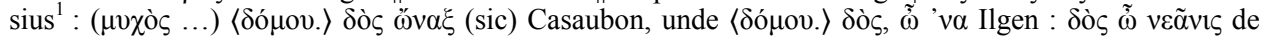

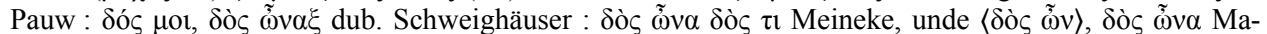

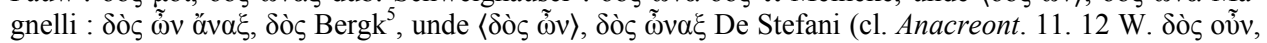

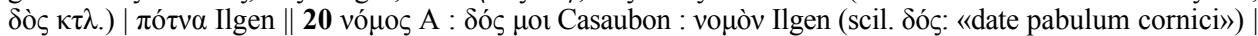

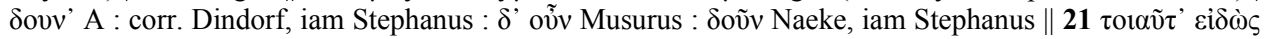




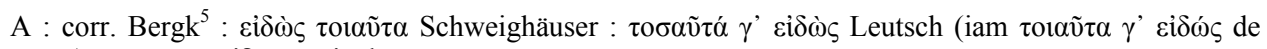

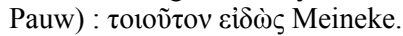

\section{F 3}

Edd.: Vit. Hom. Herod. 33. 394-396 West $=18$ s. Wilamowitz ${ }^{1}=467-480$ All. $=$ 445-462 Westermann. [Hom.] Ep. 14 Markwald. Carm. pop. 18 Edmonds = 1 Diehl. Testt.: (I) Vit. Hom. Herod. 33. 462-482 All., (II) Suda o 251 A. (= 176-197 All.).

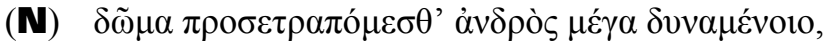

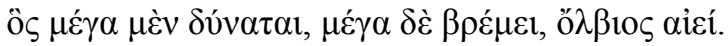

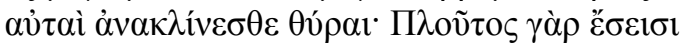

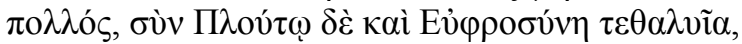

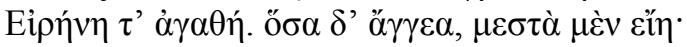

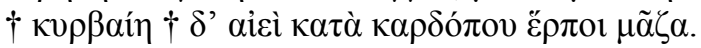

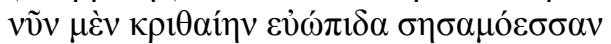

$$
\langle * * *\rangle
$$

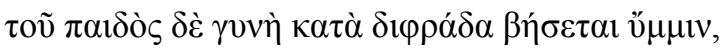

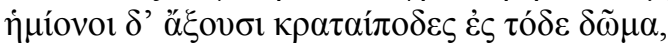

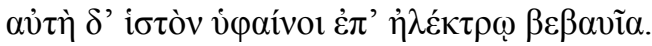

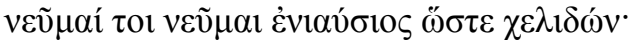

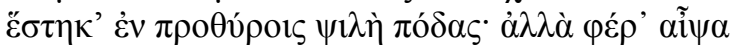

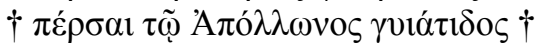

$$
\langle * * *\rangle
$$

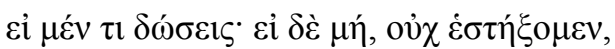

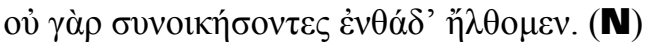

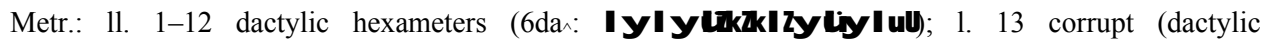
hexameter?); 11. 14s. iambic trimeters (3ia: $x \mathrm{kl} \times \mathbb{Z} \mathrm{kZ} \times \mathrm{Xl}$ kuU.

Codd.: $\mathrm{A}^{2} \mathrm{Bm}^{2} \mathrm{Bm}^{4} \mathrm{E}^{1} \mathrm{LiM}^{2} \mathrm{Ma}^{1} \mathrm{Ma}^{2} \mathrm{O}^{2} \mathrm{P}^{3} \mathrm{P}^{9} \mathrm{P}^{10} \mathrm{P}^{11} \mathrm{Pal} .{ }^{1} \mathrm{~V}^{1} \mathrm{~V}^{2}$ (I) - $\mathrm{AMG}$ (II).

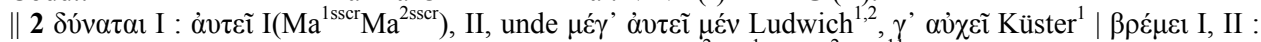

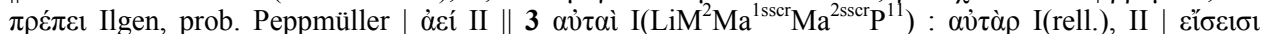

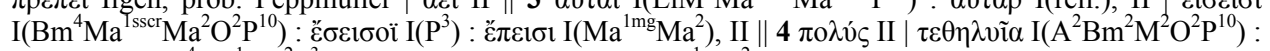

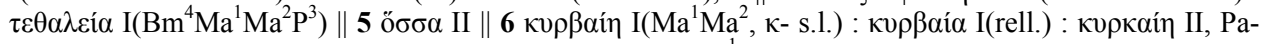

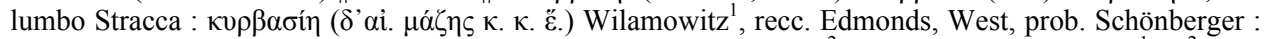

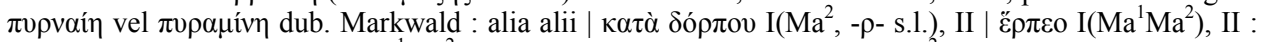

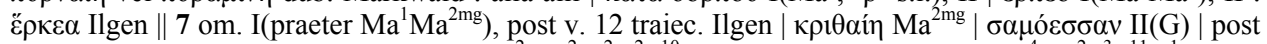
h.v. desunt nonnulli versus $\| \mathbf{8} \delta i \varphi \rho \alpha ́ \delta \alpha \mathrm{I}\left(\mathrm{A}^{2} \mathrm{Bm}^{2} \mathrm{M}^{2} \mathrm{O}^{2} \mathrm{P}^{10}\right)$, Markwald : $\delta i \varphi \rho \alpha ́ \delta o \zeta \mathrm{I}\left(\mathrm{Bm}^{4} \mathrm{Ma}^{2} \mathrm{P}^{3} \mathrm{P}^{11} \mathrm{~V}^{1}\right)$ : $\delta i ́ \varphi-$

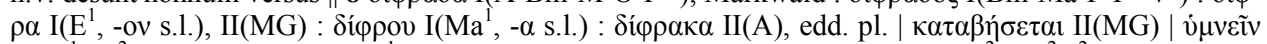

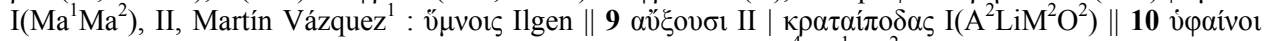

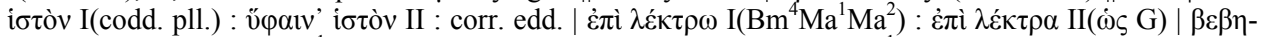

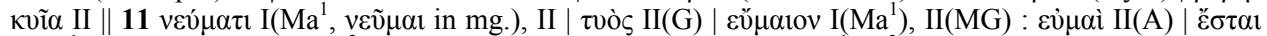

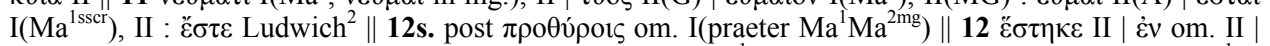

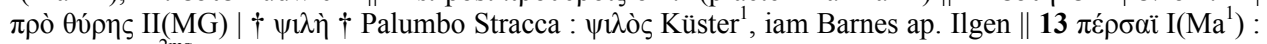

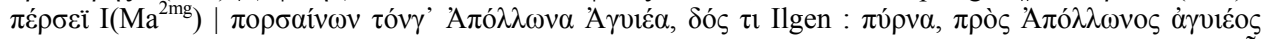

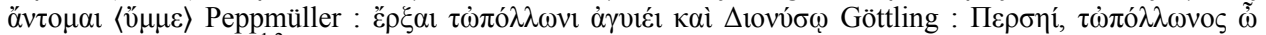

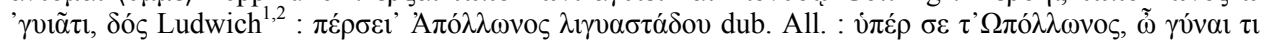




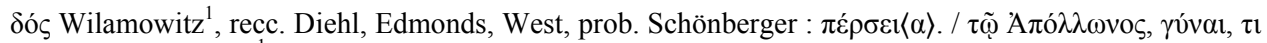

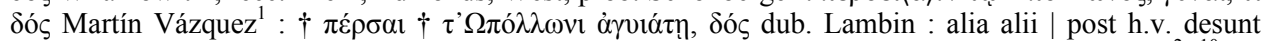

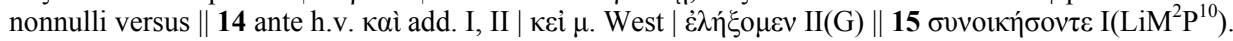

\section{F 4}

Edd.: Carm. pop. 17 Edmonds $=2$ Diehl.

Testt.: (I) Plut. Thes. 22. 6s., (II) Clem. Alex. Strom. IV 2. 7. 3, (III) schol. ${ }^{\text {VEГ囚M }}$ Ar. Eq. 729a (I) Merv. J., (IV) schol. ${ }^{\text {VE@NBarbAld }}$ Ar. Pl. 1054e Ch., (V) schol. ${ }^{\text {Pm }}$ Clem. Alex. Protr. 1. 10. 8 Marcovich, (VI) Phot. \& 254 Th., (VII) Phot. \& 255 Th., (VIII) Et. M. 303. 18-37 Gaisf. (cf. Et. Gen. AB s.v., Et. Sym. D s.v.), (IX) Suda ع1 184 A., (X) Eust. Il. 1282. 7-15, IV 666. 1-14 v.d.V., (XI) Michael Choniates, Carm. 1. 7780, (XII) Apostol. 18. 67 (CPG II 740s.). Cf. Strab. I 2. 3.

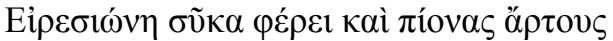

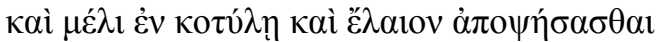

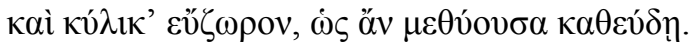

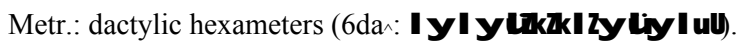

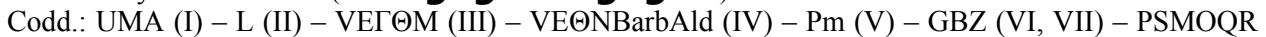
(VIII) - AMG (IX) - L (X) - L (XI) - NDO (XII).

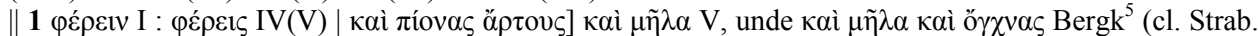

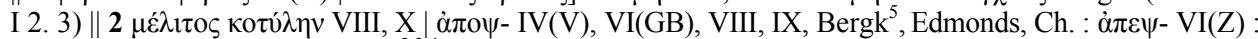

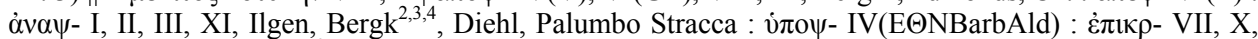

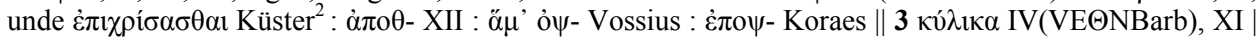

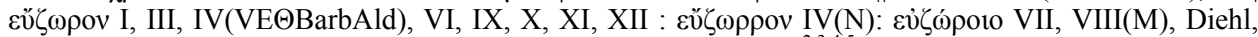

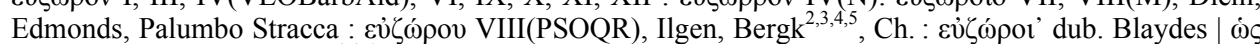

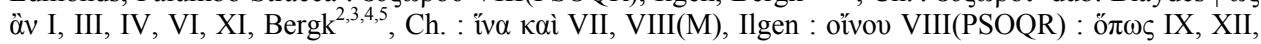

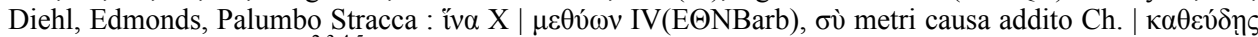

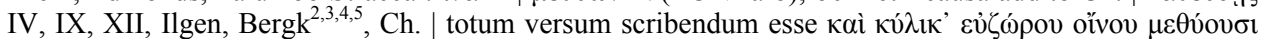
$\kappa \alpha \theta \varepsilon v ́ \delta \varepsilon ı v$ cens. Hermann ap. Sintenis.

\section{F 5}

Edd.: Carm. pop. 36 Neri $=P M G 882=19$ Edmonds $=38$ Diehl $=23$ Smyth $=42$ Bergk $^{3,4}=30$ Bergk $^{2}=18$ Bergk $^{1}=33$ Schneidewin.

Test.: Proleg. Theocr. Bb 3. 2-15 Wend.

$\delta \varepsilon \dot{\xi} \alpha \imath \tau \dot{\alpha} v \dot{\alpha} \gamma \alpha \theta \dot{\alpha} v \tau u ́ \chi \alpha \nu$,

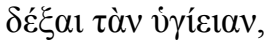

$\ddot{v} \varphi \varepsilon_{\rho} \rho \mu \varepsilon \varsigma \pi \alpha \rho \grave{\alpha} \tau \tilde{\alpha} \varsigma \theta \varepsilon o \tilde{v}$,

$\ddot{\alpha} \nu \dagger \dot{\varepsilon} \kappa \lambda \varepsilon \lambda \hat{\alpha} \sigma \kappa \varepsilon \tau \mathrm{\dagger} \dagger \tau \eta \dot{v} \alpha$.

Metr.: 11. 1 and 3 glyconics (gl: xi I kkl kl U; v. 2 pherecratean (pher: XXl kkl uU); v. 4 corrupt (pherecratean?).

Codd.: KE ${ }^{\mathrm{b}} \mathrm{AT}$.

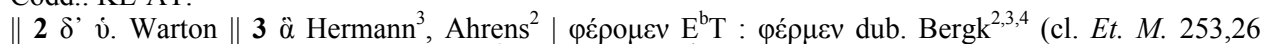
Gaisf.) $\mid \tau \tilde{\alpha} \varsigma$ post Schneidewin, Hermann ${ }^{3}$ edd. pl. : $\tau \tilde{\eta} \varsigma \mathrm{E}^{\mathrm{b}} \mathrm{AT}: \tau$ : $\tilde{\mathrm{v}} \mathrm{K} \mid \theta \varepsilon \tilde{\omega}$ Schneidewin $\| \mathbf{4} \tilde{\alpha} v \dot{\varepsilon} \kappa \lambda \varepsilon \lambda \dot{\alpha} \sigma-$

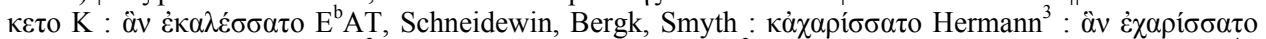

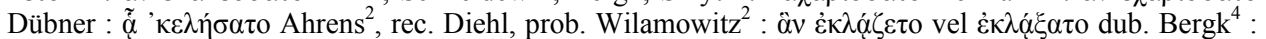

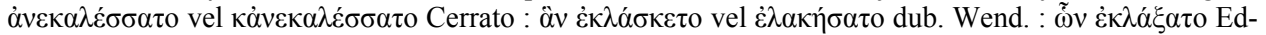

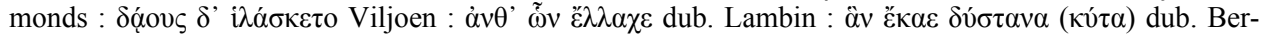
nasconi. 


\section{Sigla employed in the critical apparatus}

Ahrens $^{1}=$ AHRENS (n. 38) 478 f.

Ahrens $^{2}=$ Ahrens, H. L.: Bucolicorum Graecorum Theocriti, Bionis, Moschi reliquiae. Vol. I-II. Lipsiae 1856-1859, II 6.

Bergk $=$ Bergk $^{1+2+3+4}$.

$\operatorname{Bergk}^{1,2,3,4}=\operatorname{BERGK}$ (n. 5).

Bergk $^{5}=$ BergK, T.: Commentatio de Phoenicis Colophonii iambo. Halae 1858 (= BergK, T.: Kleine philologische Schriften. Vol. I-II. Halle 1884-1886, II 149-157).

Bernasconi $=$ BERNASCONI (n. 54).

Blaydes = BLAYDES, F. H. M.: Aristophanis Equites. Halis Saxonum 1892, 347.

Campbell ${ }^{1}=$ CAMPBELL (n. 29).

Casaubon $=a p$. Schweighäuser $[q . v$. $]$.

Cerrato $=$ CERRATO (n. 6).

Crusius $^{1}=$ CRUSIUS, O.: Herondae mimiambi. Accedunt Phoenicis coronistae, Mattii mimiamborum fragmenta. Lipsiae $1892^{1}\left(1894^{2}\right.$ [1898], $1900^{3}, 1905^{4}$ [1908], 1914 $)$.

Crusius $^{2}=$ HILLER, E.: Anthologia lyrica sive lyricorum Graecorum veterum praeter Pindarum reliquiae potiores (rev. by O. Crusius). Lipsiae 1897, LXX, 324f.

Daléchamp $=a p$. Schweighäuser [q.v.].

de Pauw = DE PAUw, J. C.: Horapollinis hieroglyphica . Trajecti a.R. 1727.

De Stefani $=$ DE STEFANI (n. 28).

Diehl $=$ DIEHL (n. 5).

Dindorf $=$ DINDORF, W.: Athenaeus. Vol. II. Lipsiae 1827, 786-789.

Dübner $=$ DÜBNER, F.: Scholia in Theocritum. Parisiis 1849, 116.

Edmonds $=$ EDMONDS (n. 5).

Furley $=$ FURLEY (n. 43).

Göttling = GöTTLING, K. W.: De Homeri Iresiona. In GöTtLING, K. W.: Opuscula academica . Lipsiae $1896,175-182$.

Gulick = GulicK, C. B.: Athenaeus. The Deipnosophists. Vol. IV. Cambridge, Mass. - London 1957, $126-132$.

Haupt $=$ HAUPT, M.: Aeschrion. Phoenix. Philologus 1 (1846) 366 (= HAUPT, M.: Opuscula. Vol. I. Lipsiae 1875, 188f.).

Hermann ${ }^{1}=$ HeRmanN, G.: De metris poetarum Graecorum et Romanorum. Vol. III. Lipsiae 1796, 337f.

Hermann $^{2}=$ HERMANN, G.: Elementa doctrinae metricae. Lipsiae 1816, 461f.

Hermann $^{3}=$ HermanN, G.: Epitome doctrinae metricae. Lipsiae $1844^{2}\left(1818^{1}\right), 210$.

Ilgen $=$ ILGEN (n. 4).

Kaibel = KAIBEL, G.: Athenaei Naucratitae Dipnosophistarum Libri XV. Vol. II. Lipsiae 1887, 286-289.

Knox $=$ Knox, A. D.: Herodes, Cercidas and the Greek Choliambic Poets (except Callimachus and Babrius). London - New York 1929 (= KNOX, A. D.: Cercidas and the Choliambic Poets. Cambridge, Mass. - London 1993).

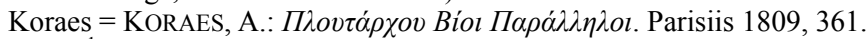

Küster $^{1}=$ KÜSTER, L.: Suidae Lexicon. Vol. II. Cantabrigiae 1705.

Küster $^{2}=$ KÜSTER, L.: Notae in Plutum. In KÜSTER, L.: Aristophanis Comoediae undecim [...]. Amstelodami 1710, 1-17.

Lambin $=$ LAMBIN (n. 6).

Leutsch = LEUTSCH, E. V.: Zu Phoenix von Kolophon. Philologus 11 (1856) 244.

Ludwich $^{1}=$ LuDwICH, A.: De Iresione carmine Homerico dissertatio. Regimonti 1906.

Ludwich $^{2}=$ LUDWICH, A.: Homerische Gelegenheitsdichtungen. RhM n. F. 71 (1916) 200-231.

Magnelli $=a p$. DE STEFANI (n. 28).

Markwald $=$ MARKWALD (n. 26).

Martín Vázquez ${ }^{1}=$ MARTín VÁZQUEZ, L.: La canción de la eiresione samia. Minerva 4 (1990) 38-52.

Martín Vázquez ${ }^{2}$ = MARTín VÁzQuEZ, L.: The Song of the Swallow. $C F C(G) 9$ (1999) 23-38.

Meineke = MeINEKE, A.: Athenaei Deipnosophistae. Vol. II. Lipsiae 1858, 153-155 (with Analecta critica ad Athenaei Deipnosophistas. Lipsiae 1867, 157-159).

Morelli $=$ MORELLI (n. 27). 


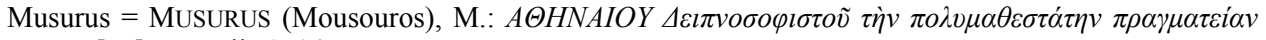
[...]. Venetiis 1514 .

Naeke = NAEKE, A. F.: Choerili Samii quae supersunt . Lipsiae 1817.

Neri $=$ NERI (n. 5).

Olson $=$ Olson, S. D.: Athenaeus. The Learned Banqueters. Vol. IV. Cambridge, Mass. - London 2008, $144-150$

Page $=$ PAGE (n. 5) .

Palumbo Stracca $=$ PALUMBO STRACCA ${ }^{1,2}$ (n. 26).

Peppmüller $=$ PEPPMÜLLER, R.: Drei bei Umgangen in Griechenland gesungene Bettlieder. JKPh 149 (1894) 15-25.

Pordomingo $=$ PORDOMINGO (n. 6).

Powell = POWELL, J. U.: Collectanea Alexandrina. Oxonii 1925.

Rossbach $=a p$. Powell [q.v.].

Ruhnkenius $=$ RUHNKENIUS, D.: Timaei Lexicon Vocum Platonicarum . Lipsiae $1828^{3}$ (Lugduni Batavorum $\left.1789^{2} ; 1754^{1}\right)$.

Schneidewin $=$ SCHNEIDEWIN (n. 5) .

Schönberger $=$ SCHÖNBERGER (n. 26).

Schweighäuser = SCHWEIGHÄUSER, J.: Athenaei Naucratitae Deipnosophistarum Libri XV. Vol. III. Argentorati 1803, 326-329 (with Animadversiones in Athenaei Deipnosophistas. Vol. IV. Argentorati $1803,652-662$ ).

Sintenis $=$ SINTENIS, C.: Plutarchi Vitae Parallelae. Vol. I. Lipsiae 1858, VI.

Smyth $=$ SMYTH (n. 5).

Stephanus $=$ ThGL III 1380 .

Usener $=$ USENER, H.: Der altgriechische Versbau . Bonn 1887, 81-83.

Viljoen = VILJOEN, H. G.: Notes on Lyra Graeca. Mnemosyne 4 s. 5 (1952) 227.

Vossius = Vossius, I.: Observationes ad Pomponium Melam de situ orbis. Hagae Comitis 1658, 78.

Warton $=$ WARTON, T.: Theocriti Syracusii quae supersunt. Oxonii 1770, lxvi.

West = WeSt, M. L.: Homeric Hymns, Homeric Apocrypha, Lives of Homer. Cambridge, Mass. - London 2003.

Westermann = WESTERMANN, A.: ВIОГР AФOI. Vitarum scriptores Graeci minores. Brunsvigae 1845.

Wilamowitz $^{1}=$ WILAMOWITZ (n. 27).

Wilamowitz $^{2}=$ WILAMOWITZ-MOELLENDORFF, U. vON: Griechische Verskunst. Berlin 1921, 230f., 400.

Antonio Genova

King's College London

antonio.genova@kcl.ac.uk 
